\title{
PENERAPAN PROBLEM BASED-LEARNING MELALUI LESSON STUDY PADA PEMBELAJARAN PPKN UNTUK MENINGKATKAN PARTISIPASI AKTIF DAN KERJASAMA SISWA DALAM DISKUSI KELOMPOK
}

\author{
Ken Restisiwi ${ }^{1}$, Lutfi Istikharoh ${ }^{2}$ \\ ${ }^{1}$ MTs Muhammadiyah 01 Purbalingga \\ ${ }^{2}$ FKIP Universitas Muhammadiyah Purwokerto, email: \\ lutfiistikharoh@ump.ac.id
}

\begin{abstract}
This article presents the result of implementing Problem-based Learning through Lesson Study in Civics class as an effort of enhancing students' participation and collaboration during class discussions. The implementation of Problem-based Learning through Lesson Study was conducted in a private school under Muhammadiyah organization in Distric Purbalingga, Central Java, namely MTs Muhammadiyah 01 Purbalingga. In Civics Class at the school investigated, the learning process was commonly dominated by lecturing session which made the students passive and found monotonous atmosphere of learning which consequently resulted on meaningless learning. This condition affected to the students' activeness which belonged to low category. Therefore a better design of learning by implementing Problem-based Learning through Lesson Study was needed to cope with the problem. Lesson Study was done in 2 cycles and is still continuing until now. The action was intended to make the students more active and participative during the Civics lesson especially in class discussion sessions. The method which was used is qualitative method with 36 students in grade $8 E$ of MTs Muhammadiyah 01 Purbalingga participated. During two times of plan-do-see actions in Lesson Study, 8 of 9 groups in Civics class or $80 \%$ of the whole students was good at participating in group and class discussions. The finding found in the two cycles of Lesson Study gives a proof that the implementation of Problem-based Learning contributes positively to the students' participation and collaboration in Civics class.
\end{abstract}

Keywords: Plan, Do, See, Participation, Collaboration

\begin{abstract}
ABSTRAK
Penerapan Problem based-learning melalui Lesson Study dalam Pembelajaran PPKn untuk Meningkatkan Partisipasi Aktif Siswa dalam diskusi kelompok. Penerapan Penggunaan metode ceramah membuat siswa menjadi pasif dan monoton dalam belajar sehingga suasana pembelajaran menjadi kurang hidup. Kondisi tersebut berdampak pada kurangnya partisipasi aktif siswa dalam kegiatan pembelajaran. Lesson Study dalam 2
\end{abstract}


siklus telah dilaksanakan dan masih berlanjut guna meningkatkan partisipasi siswa dalam kegiatan diskusi. Penerapan Lesson Study ini bertujuan untuk mengetahui upaya dalam meningkatkan partisipasi aktif siswa melalui kegiatan diskusi kelompok pada mata pelajaran PPKn. Pendekatan yang digunakan adalah pendekatan kualitatif, objek pengamatan adalah 36 siswa kelas VIII E MTs Muhammadiyah 01 Purbalingga. Penerapan Lesson Study dilaksanakan melalui tiga tahap yaitu Plan (Perencanaan), Do (Pelaksanaan), See ( Refleksi). Dalam pelaksanaan 2 siklus Lesson Study, 8 dari 9 kelompok (80\%) telah mampu berpartisipasi aktif dalam diskusi kelompok maupun diskusi kelas. Hal ini menunjukkan bahwa pelaksanaan Lesson Study memberikan manfaat bagi peningkatan partisipasi aktif siswa.

Kata Kunci: Plan, Do, See, kerjasama, kolaborasi

\section{PENDAHULUAN}

Pembelajaran Pendidikan Kewarganegaraan (yang selanjutnya disebut PPKn) merupakan mata pelajaran yang memiliki tujuan untuk mengakomodasi siswa dalam mengapresiasi pesan pesan moral. Fokus mata pelajaran PPKn adalah pada pembentukan karakter diri yang beragam dimensi dari dimensi agama, sosio-cultural, bahasa, usia dan suku bangsa untuk menjadi warga negara Indonesia yang cerdas, terampil dan berkarakter yang dilandasi Pancasila dan UUD 1945 (Depdiknas, 2006: 49).

Dalam proses pembelajaran Pendidikan Kewarganegaraan yang memfokuskan pembentukan karakter warga negara Indonesia yang cerdas, terampil sesuai dengan Pancasila dan UUD 1945 tersebut hendaknya semua pihak berusaha mewujudkan pembelajaran yang dapat melibatkan siswa dan merangsang ketrampilan berpikir dan ketrampilan sosialnya. Dengan demikian partisipasi aktif siswa meningkat.

Pada kenyataannya, pembelajaran PPKn masih menjadi mata pelajaran yang kurang menarik bahkan membosankan bagi siswa. Hal ini dikarenakan substansinya masih menuntut siswa untuk menghafal materi pembelajaran. Permasalahan menjadi lebih berat bagi siswa karena pembelajarannya hanya mendengarkan ceramah dari guru, bertanya jawab dan mengerjakan tugas secara individu. Akibatnya, siswa cenderung pasif dalam proses pembelajaran di kelas.

Peningkatan partisipasi aktif siswa dan belajar siswa tidak terlepas dari peran guru sebagai tenaga pengajar. Oleh karena itu guru sangat berpengaruh terhadap proses belajar mengajar di kelas. Pemilihan model pembelajaran yang 
tepat dalam pembelajaran Pendidikan Kewarganegaraan dapat meningkatkan partisipasi aktif siswa dalam proses pembelajaran.

Siswa kelas VIII E MTs Muhammadiyah 01 Purbalingga masih kurang aktif dalam proses pemeblajaran dikelas, masih pasif dan sekeder hanya mendengarkan penjelasan dari guru. Penerapan Kurikulun 2013 siswa dituntut berperan aktif dalam proses pembelajaran, peran guru dalam pembelajaran sebagai fasilitator dan motivator.

Berawal dari masalah tersebut guru melaksanakan Lesson Study untuk meningkatkan partisipasi aktif siswa kelas VIII E MTs Muhammadiyah 01 Purbalingga, Lesson Study bukan metode atau strategi pembelajaran, tetapi kegiatan Lesson Study dapat menerapkan beberapa metode atau strategi pembelajaran yang sesuai situasi atau kondisi dan permasalahan yang dihadapi.

Lesson Study dilaksanakan denga tiga tahapan yaitu perencanaan (Plan), pelaksanaan (Do), dan melihat kembali atau refleksi (See), Ketiga tahapan tersebut dilakukan secara berulang. Tahap perencanaan (Plan) bertujuan untuk menghasilkan rancangan pembelajaran yang diyakini mampu membelajarkan siswa secara efektif dan membangkitkan partisipasi siswa dalam pembelajaran.Tahap Pelaksanaan (Do) dimaksud untuk penerapan rancangan pembelajaran yang telah direncanakan. Tahap pengamatan dan refleksi (See) dimaksudkan untuk menemukan kelebihan dan kekurangan pelaksanaan pembelajaran. Serangkaian kegiatan mulain tahap Plan sampai See dilakukan secara kolaboratif (Susilo, 2009:34-36)

\section{A. Problem based-learning}

Model pembelajaran Problem Based Learning adalah model pembelajaran dengan pendekatan pembelajaran siswa pada masalah autentik sehingga siswa dapat menyusun pengetahuannya sendiri, menumbuh kembangkan ketrampilan yang lebih tinggi dan inkuiri, memandirikan siswa dan meningkatkan kepercayaan diri sendiri (menurut Arends dalam Abbas, 2000:13). Model ini bercirikan penggunaan masalah kehidupann nyata sebagai sesuatu yang harus dipelajari siswa untuk melatif dan meningkatkan ketrampilan berfikir kritis dan pemecahan masalah serta mendapatkan pengetahuan konsep-konsep penting, dimana tugas guru harus memfokuskan diri untuk membantu siswa mencapai ketrampilan mengarahkan diri. Problem Based Learning atau pembelajaran berbasis masalah meliputi pengajuan pertanyaan atau masalah, memusatkan keterkaitan antar disiplin, 
penyelidikan autentik, kerjasama dan menghasilakan karya serta peragaan. Pembelajaran berbasis masalah tidak dirancang untuk membantu guru memberikan informasi sebanyak-banyak kepada siswa. Pembelajaran berbasis masalah anatara lain bertujuan membantu siswa mengembangkan ketrampilan berfikir dan ketrampilan pemecahan masalah (Ibrahim 2002).

\section{B. Partisipasi aktif}

Partisipasi berasal dari bahasa Inggris yaitu "participation" adalah pengambilan bagian atau pengikut sertaan. Menurut Keith Davis, partisipasi adalah suatu keterlibatan mental dan emosi seseorang kepada pencapaian tujuan dan ikut bertanggung jawab di dalamnya. Dalam defenisi tersebut kunci pemikirannya adalah keterlibatan mental dan emosi. Sebenarnya partisipasi adalah suatu gejala demokrasi dimana orang diikutsertakan dalam suatu perencanaan serta dalam pelaksanaan dan juga ikut memikul tanggung jawab sesuai dengan tingkat kematangan dan tingkat kewajibannya. Partisipasi itu menjadi baik dalam bidang-bidang fisik maupun bidang mental serta penentuan kebijaksanaan.

\section{Lesson study}

Konsep dan praktik Lesso Study pertama kali di kembangkan oleh para guru pendidikan dasar di Jepang, yang dalam bahasa Jepang-nya disebut dengan istilah kenkyuu jugyo. Adalah Makoto Yoshida, orang dianggap berjasa besar dalam mengembangkan kenkyuu jugyo di Jepang.

Lesson Study bukanlah suatu strategi atau metode dalam pembelajaran, tetapi merupakan slah satu upaya pembinaan untuk meningkatkan proses pembelajaran yang dilakukan oleh sekelompok guru secara kolaboratif dan berkesinambungan, dalam merencanakan, melaksanakan, mengobeservasi dan melaporkan hasil pembelajaran. Menurut Wikipedia (2007) Bahwa Lesson Study dilakukan melalui empat tahapan dengan menggunakan konsep Plan-Do-Check-Act (PDCA). Sementara itu, Slamet Mulyono (2007) mengemukakan tiga tahapan dalam Lesson Study, yaitu : (1) Perencanaan (Plan); (2) Pelaksanaan (Do) dan (3) Refleksi (See). Untuk lebih jelasnya dengan merujuk pada pemikiran Slamet Mulyono (2007), dibawah ini akan diuraikan secara ringkas tiga tahapan dalam penyelenggaraan Lesson Study: 1. Tahapan Perencanaan (Plan) 
Dalam tahap perencanaan para guru yang tergabung dalam Lesson Study berkolaborasi dalam menyusun RPP yang mencerminkan pembelajaran yang berpusat pada siswa. Perencanaan diawali dengan kegiatan menganalisis kebutuhan dan permasalahan yang dihadapi pembelajaran.

2. Tahap Pelaksanaan (Do)

Pada tahapan kedua, terdapat dua kegiatan utama yaitu: (1) kegiatan pelaksanaan pembelajaran yang dilakukan oleh salah seorang guru yang disepakati atau atas permintaan sendiri untuk mempraktekkan RPP yang telah disusun bersama, dan (2) kegiatan pengamatan atau observasi yang dilakukan oleh anggota atau komunitas Lesson Study lainnya.

3. Tahap Refleksi (See)

Tahapan ke tiga merupakan tahapan yang penting karena upaya perbaikan proses pembelajaran selanjutnya akan bergantung pada ketajaman analisis para peserta berdasarkan pengamatan terhadap pelaksanaan pembelajaran yang telah dilaksanakan. Kegiatan refleksi dilakukan dalam bentuk diskusi yang diikuti seluruh peserta Lesson Study.

\section{PROSEDUR PELAKSANAAN}

Pelaksanaan pembelajaran Lesson Study dalam pembelajaran mata pelajaran PPKn untuk meningkatkan partisipasi aktif siswa kelas VIII E MTs Muhammadiyah 01

Purbalingga dapat dijabarkan sebagai berikut:

Penerapan Problem based-learning melalui Lesson Study dalam Pembelajaran PPKn untuk Meningkatkan Partisipasi Aktif Siswa dalam diskusi kelompok

\section{Kegiatan Siklus ke-1}

\section{a. Perencanaan (Plan)}

Pada tahap perencanaan guru menyusun RPP yang mencerminkan pembelajaran yang berpusat pada siswa, Dengan adanya RPP ini kegiatan belajar mengajar akan terarah sesuai dengan materi yang tersusun. Guru menyiapkan perangkat pembelajaran berupa lembar pertanyaan yang akan di diskusikan siswa secara berkelompok. 


\section{b. Pelaksanaan (Do)}

Pada tahap pelaksanaan pertemuan ke-1 dilaksanakan pada hari Sabtu, 16 Februari 2019 pada jam ke 3 dan 4 selama 80 menit.

Pelaksanaan tindakan yang dilakukan adalah merujuk pada skenario pembelajaran yang telah di rancang yang itu diskusi dengan kelompok homogen

a) Kegiatan Awal

Pembelajaran diawali dengan salam pembuka, mengkondisikan kelas, berdoa dan mengabsen kehadiran siswa. Kemudian melakukan apersepsi dengan terlebih dahulu menyampaikan indikator pembelajaran yang harus dicapai, kemudian mengecek kemampuan siswa dengan menanyakan materi yang telah disampaikan waktu lalu.

b) Kegiatan Inti

Pada awal kegiatan inti sebelum guru membagi siwa dalam kelompok terlebih dahulu menyampaikan point-point materi pembelajaran tentang makna Sumpah Pemuda. Kemudian guru membagi kelompok kecil dan memberikan tugas kelompok. Setiap kelompok terdiri dari 4 (empat) siswa homogen. Guru menjelaskan tugas kelompok yang diberikan kemudian masing-masing kelompok mendiskusikan dan mempresentasikan hasil pekerjaannya di depan kelas.

c) Kegiatan Penutup

Kegiatan akhir dalam pembelajaran ini, guru menanyakan materi yang belum dimengerti dan melakukan refleksi dengan mengarahkan siswa untuk menyimpulkan materi dan guru memberikan pesan moral kepada siswa dari kegiatan pembelajaran yang telah dilaksanakan.

\section{c. Refleksi (See)}

Setelah kegiatan pembelajaran dilaksanakan guru dan observer merefleksi jalannya kegiatan pembelajaran kelas VIII E MTs Muhammadiyah 01 Purbalingga. Kegiatan refleksi dilaksanakan pada hari Sabtu 16 Februari 2019. Kegiatan ini dilakukan dalam bentuk diskusi yang diikuti oleh guru model dan observer. Diskusi dimulai dengan penyampain kesan dan komentar kegiatan pembelajaran yang sudah dilakukan oleh guru model dan observer. Berikut hasil pengamat pada siklus : 


\section{Hasil Observasi Pengamat 1}

1) Partisipasi Aktif siswa

Menurut observer pembelajaran sudah cukup baik dan kondusif. Namun pada saat penugasan kelompok masih ada beberapa siswa yang kurang partisipasi aktif dalam mengerjakan tugas kelompok. Masih ada 2 sampai 3 siswa yang diam tidak aktif dalam kelompoknya. Hal ini mengakibatkan partisipasi aktif di dalam kelompok kurang.

2) Kerja sama

Kerja sama siswa dalam kelompok masih terlihat ada 2 sampai 3 siswa yang belum fokus pada tugasnya tetapi malah asyik mengobrol dengan temannya.

\section{Hasil Observasi Pengamat 2}

1) Partisipasi Aktif Siswa

Partisipasi aktif siswa dalam kelompok sedikit terpengaruh akan pembagian kelompok secara homogen. Hal ini mengakibatkan kelompok laki-laki cenderung lebih pasif di banding kelompok perempuan

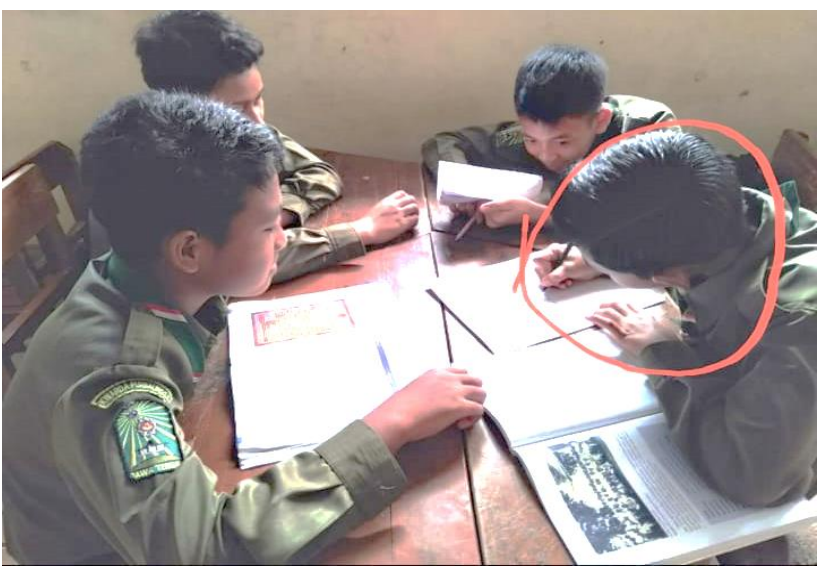

Gambar 1. Hanya satu siswa putra yang aktif mengerjakan tugas

2) Kerja sama

Kerja sama siswa pada saat presentasi hasil diskusi di depan kelas kelompok perempuan lebih aktif dan lebih baik pada saat mengungkapkan pendapatnya maupun pada saat merespon kelompok lain. 


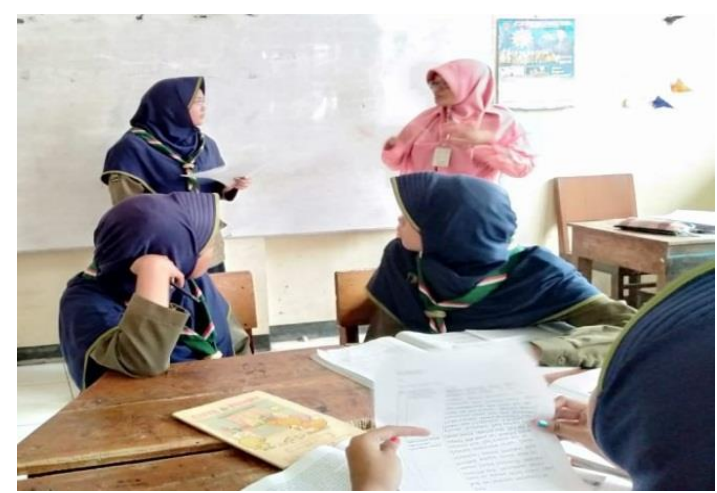

Gambar 2. Siswa putri lebih aktif dan antusias mempresentasikan hasil diskusi kelompok

\section{Grafik Peningkatan Partisipasin Aktif Siswa}

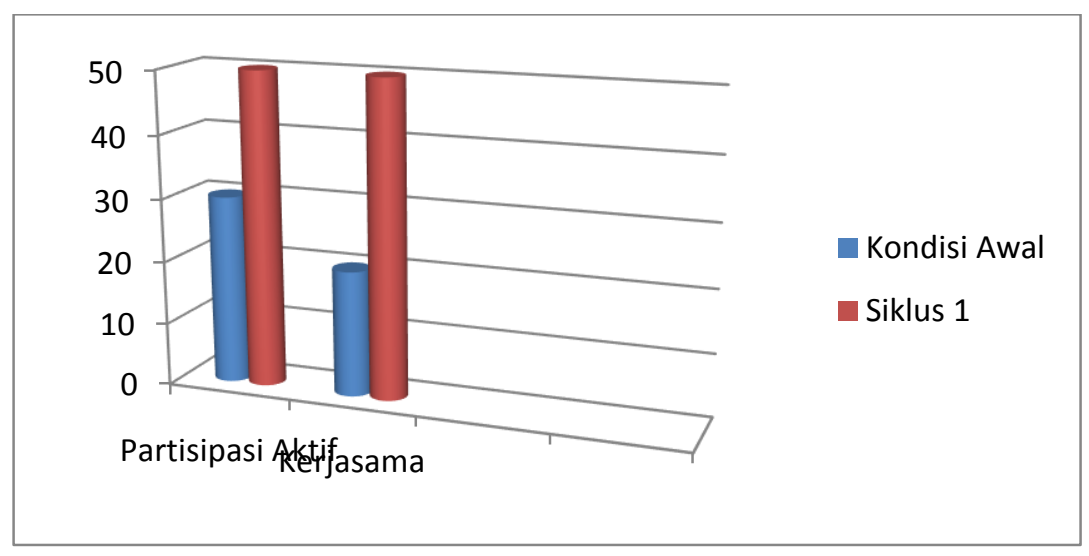

\section{Kegiatan Siklus ke-2}

Pada kegiatan pertemuan ke-2 ini juga terdiri dari tiga tahapan sebagai berikut:

a. Perencanaan (Plan)

Pada pertemuan ke-2 guru menyusun RPP dengan materi yang berbeda dengan pertemuan ke-1. Pada pertemuan ke-2 materi "Arti Penting Sumpah Pemuda Bagi Perjuangan Bangsa Indonesia”. Perbedaan yang lain adalah pembagian kelompok heterogen. Guru menyiapkan perangkat pembelajaran berupa lembar pertanyaan yang akan di diskusikan siswa secara berkelompok.

\section{b. Pelaksanaan (Do)}

Pada tahap pelaksanaan pertemuan ke-2 dilaksanakan pada hari Sabtu, 23 Februari 2019 pada jam ke 3 dan 4 selama 80 menit. 
Pelaksanaan tindakan yang dilakukan adalah merujuk pada skenario pembelajaran yang telah di rancang yaitu diskusi dengan kelompok heterogen

\section{a) Kegiatan Awal}

Pembelajaran diawali dengan salam pembuka, mengkondisikan kelas, berdoa dan mengabsen kehadiran siswa. Kemudian melakukan apersepsi dengan terlebih dahulu menyampaikan indikator pembelajaran yang harus dicapai, sebelum masuk materi pembelajaran mengecek kemampuan siswa dengan menanyakan materi yang telah disampaikan waktu lalu dalam bentuk tanya jawab.

b) Kegiatan Inti

Pada kegiatan inti guru memulai pembelajaran dengan memberikan contoh siswa yang memiliki jiwa semangat sumpah pemuda. Selanjutnya guru menyampaikan poin-poin materi pembelajaran "Arti Penting Sumpah Pemuda Bagi Perjuangan Indonesia". Kemudian guru membagi kelompok kecil dan memberikan tugas kelompok. Setiap kelompok terdiri dari 4 s(empat) siswa heterogen. Guru menjelaskan tugas kelompok yang diberikan kemudian masing-masing kelompok mendiskusikan dan mempresentasikan hasil pekerjaannya di depan kelas

c) Kegiatan Penutup

Kegiatan akhir dalam pembelajaran ini, guru menanyakan materi yang belum dimengerti dan melakukan refleksi dengan mengarahkan siswa untuk menyimpulkan materi dan guru memberikan pesan moral kepada siswa dari kegiatan pembelajaran yang telah dilaksanakan.

\section{c. Refleksi (See)}

Setelah kegiatan pembelajaran dilaksanakan guru model dan observer merefleksi jalannya pembelajaran. Kegiatan refleksi pertemuan ke-2 dilaksanakan pada hari Sabtu, 23 Februari 2019. Kegiatan ini dilakukan dalam bentuk diskusi yang diikuti oleh guru model dan observer. Diskusi dimulai dengan penyampain kesan dan komentar kegiatan pembelajaran yang sudah dilakukan oleh guru model. Berdasarkan hasil pengamatan observer siwa mengikuti jalan kegiatan pembelajaran dengan baik dan sudah ada peningkatan partisipasi aktif siswa dan kerja sama dalam kelompok. Berikut hasil pengamtan pada siklus 2: 


\section{Hasil Observasi Pengamat 1}

\section{1) Partisipasi Aktif Siswa}

Partisipasi siswa mengalami peningkatan, hampir seluruh siswa terlibat aktif dalam mengerjakan tugas kelmpok, ada yang mencatat hasil diskusi, memberikan masukan/pendapat untuk menyelesaikan tugas kelompok

2) Kerja sama

Kerja sama masing-masing kelompok pada saat presntasi hasil diskusi di depan kelas saling bekerja sama saat memberikan jawaban pertanyaan dari kelompok lain. Dari 9 kelompok 7-8 kelompok saling mersepon pada saat prsentasi

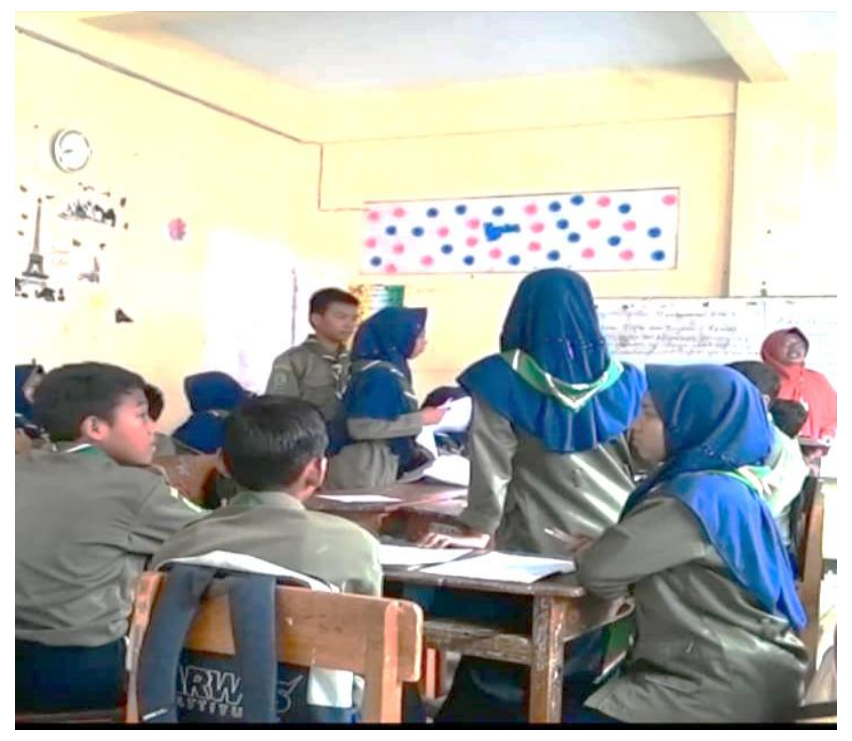

Gambar 3. Siswa terlibat aktif dalam diskusi antar kelompok

\section{Hasil Observasi Pengamat 2}

1) Partisipasi Aktif Siswa

Pada siklus ke 2 pembagian kelompok heterogen, siswa laki-laki mulai aktif memainkan perannya dan bertanggung jawab menyelesaikan tugas kelompoknya. Hal ini di buktikan dengan partisipasi aktif siswa lakilaki dari kelompok 7 memimpin dan mempresentasikan hasil diskusi di depan kelas. 


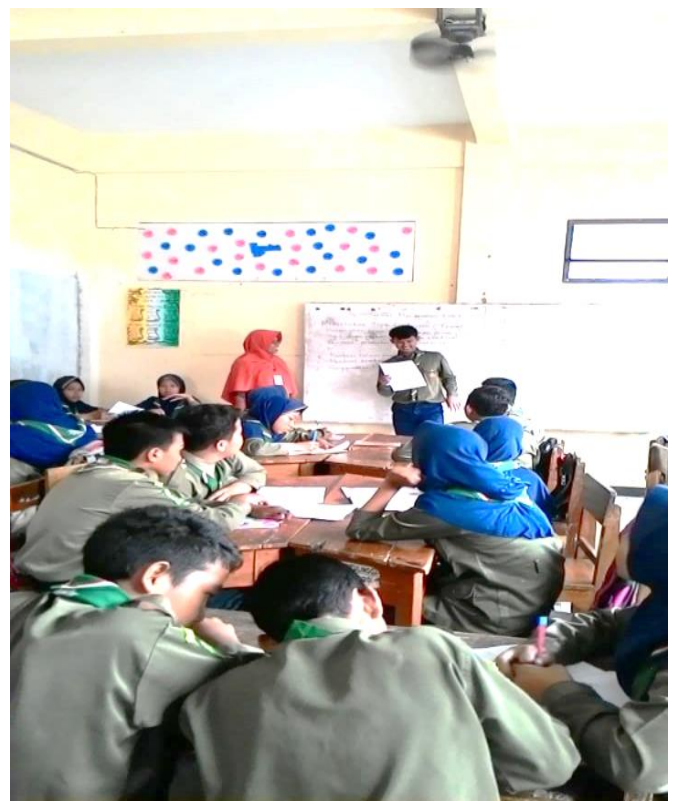

Gambar 4. Siswa laki-laki mempresentasikan hasil diskusi

2) Kerja sama

Kerjasa sama antar anggota kelompok mengalami peningkatan. Hanya ada 1 kelompok yang kurang bisa bekerja sama antar anggota. Dimungkinkan karena di dalam kelompok tersebut kurang bertanggung jawab atas tugas yang diberikan oleh guru.

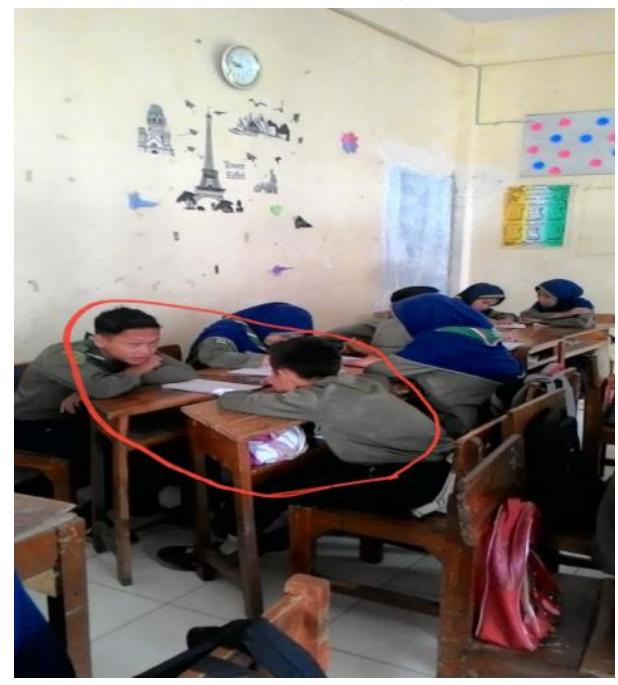

Gambar 5. Dua siswa tidak bekerjasama menyelesaikan tugas. 


\section{Grafik Peningkatan Partisipasi Aktif Siswa}

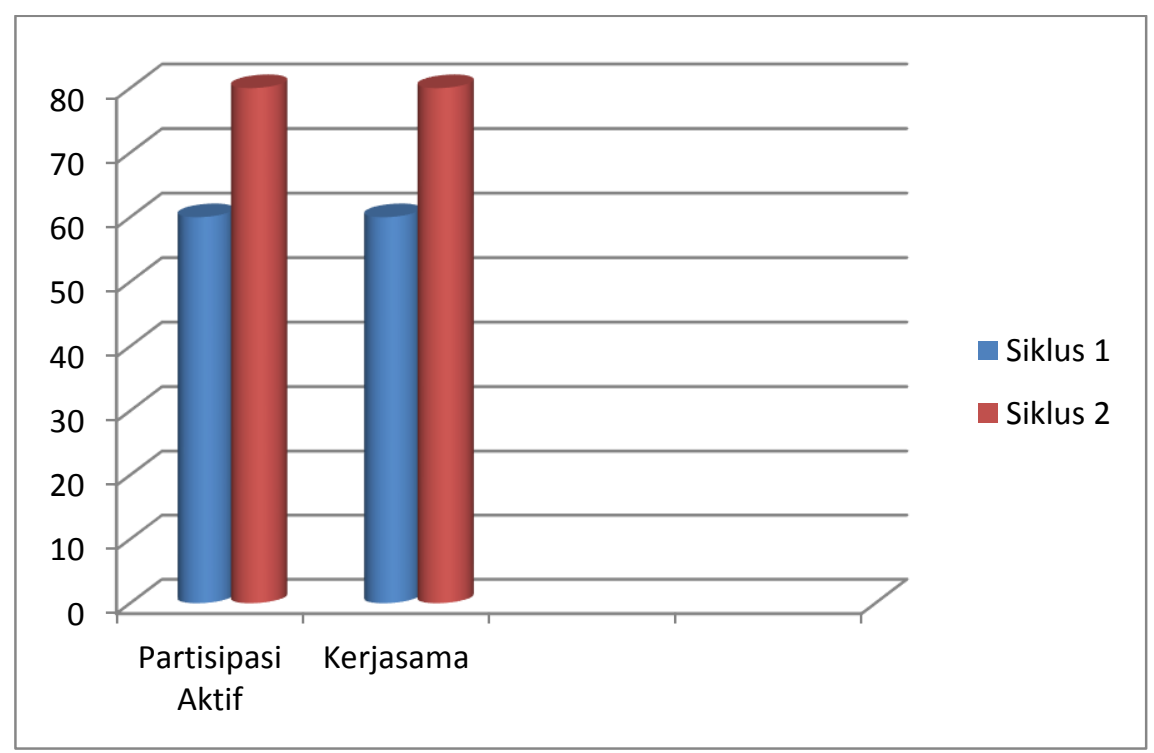

\section{PENUTUP}

\section{Simpulan}

Berdasarkan uraian pelaksanaan kegiatan pembelajaran selama dua kali pertemuan pembelajaran maka dapat diambil kesimpulan sebagai berikut:

1. Lesson Study sebagai salah satu alternatif guna mengatasi masalah praktik pembelajaran di kelas VIII E MTs Muhammadiyah 01 Purbalingga yang selama ini dipandang kurang efektif

2. Pelaksanaan Lesson Study dilaksanakan dengan tiga tahapan yaitu: (1) perencanaan (plan) meliputi kegiatan penyusunan RPP dan penentuan model pembelajaran, pelaksanaan (Do) dalam kegiatan pembelajaran di kelas VIIIE MTs Muhammadiyah 01 Purbalingga, dan refleksi (See) untuk menjabarkan hasil penelitian

3. Pelaksanaan Lesson Study pada mata pelajaran PPKn dapat meningkatkan partisipasi aktif siswa kelas VIII E MTs Muhammadiyah 01 Purbalingga

4. Melalui Lesson Study guru menjadi peka terhadap permasalahan pembelajaran sehingga menjadikan guru lebih kreatif dalam memilih dan menentukan model/metode pembelajaran sehingga dapat meningkatkan partisipasi aktif siswa selama pembelajaran 


\section{Saran}

Pelaksanaan pembelajaran dengan pengelompokan siswa (diskusi) melalui Lesson Study disarankan untuk secara rutin atau berskala dilaksanakan oleh guru karena kegiatan tersebut sangat positif untuk meningkatakan partisipasi akif siswa

\section{DAFTAR PUSTAKA}

Depdiknas. 2006. Permendiknas Nomor 22 tentang Standar Isi Tujuan Pembelajaran PKn. Jakarta.

Ibrahim M \& M. Nur. 2000. Pembelajaran Berdasar Masalah. Surabaya: UNESAUniversity Press.

Slamet Mulyana. 2007. Lesson Study (Makalah). Kuningan: LPMP. Jawa Barat Susilo, Herawati, dkk. 2009. Lesson Study Berbasis Sekolah. Malang: Bayumedia Publising.

Wikipedia. 2007. Lesson Study.en.wikipedia.org/wiki/Lesson_Lesson_study. 